Research Article

\title{
Tailored Centrifugal Turbomachinery for Electric Fuel Cell Turbocharger
}

\author{
Dietmar Filsinger $\mathbb{D}^{1},{ }^{1}$ Gen Kuwata $\mathbb{D},{ }^{2}$ and Nobuyuki Ikeya $\mathbb{D}^{3}$ \\ ${ }^{1}$ IHI Charging Systems International GmbH, 69168 Heidelberg, Germany \\ ${ }^{2}$ IHI Corporation, Corporate Strategy Headquarters, Tokyo 135-8710, Japan \\ ${ }^{3}$ IHI Corporation, Vehicular Turbocharger Business Unit, Yokohama 235-8501, Japan \\ Correspondence should be addressed to Dietmar Filsinger; d.filsinger@ihi-csi.de
}

Received 23 April 2021; Revised 4 August 2021; Accepted 20 August 2021; Published 27 September 2021

Academic Editor: Gerard Bois

Copyright (c) 2021 Dietmar Filsinger et al. This is an open access article distributed under the Creative Commons Attribution License, which permits unrestricted use, distribution, and reproduction in any medium, provided the original work is properly cited.

\begin{abstract}
Hydrogen fuel cell technology is identified as one option for allowing efficient vehicular propulsion with the least environmental impact on the path to a carbon-free society. Since more than 20 years, IHI is providing charging systems for stationary fuel cell applications and since 2004 for mobile fuel cell applications. The power density of fuel cells substantially increases if the system is pressurized. However, contaminants from fuel cell system components like structural materials, lubricants, adhesives, sealants, and hoses have been shown to affect the performance and durability of fuel cells. Therefore, the charging system that increases the pressure and the power density of the stacks inevitably needs to be oil-free. For this reason, gas bearings are applied to support the rotor of a fuel cell turbocharger. It furthermore comprises a turbine, a compressor, and, on the same shaft, an electric motor. The turbine utilizes the exhaust energy of the stack to support the compressor and hence lower the required electric power of the air supply system. The presented paper provides an overview of the fuel cell turbocharger technology. Detailed performance investigations show that a single-stage compressor with turbine is more efficient compared to a twostage compressor system with intercooler. The turbine can provide more than $30 \%$ of the required compressor power. Hence, it substantially increases the system efficiency. It is also shown that a fixed geometry turbine design is appropriate for most applications. The compressor is of a low specific speed type with a vaneless diffuser. It is optimized for operating conditions of fuel cell systems, which typically require pressure ratios in the range of 3.0.
\end{abstract}

\section{Introduction}

One contribution for achieving the global $\mathrm{CO}_{2}$ reduction emission targets agreed on in the Paris convention needs to come from low or even zero emission vehicle propulsion technology. Options for zero emission propulsion are discussed and investigated in great detail. One exemplary study is the study "energy paths for road transport in the future." The condensed results are published in [1]; the detailed study can be found in [2].

Based on tank-to-wheel emissions, only electric propulsion allows zero (vehicle) emissions. Options to store the energy on board are batteries or hydrogen $\left(\mathrm{H}_{2}\right)$. Energy den- sity based on weight, but also on volume of $\mathrm{H}_{2}$, pressurized to 750 bar, is multiple times higher compared to batteries, no matter what battery type is considered [3]. Also, the duration for refuelling with $\mathrm{H}_{2}$ compared to charging time of batteries is in clear favour of fuel cell systems. Therefore, the more a mobile application needs to serve missions that allow only minimal down times and request high payloads and/or long range, the more $\mathrm{H}_{2}$ fuel cell systems are the appropriate choice for providing energy for the electric propulsion system. Long haul missions of heavy-duty truck applications are therefore most suitable for applying $\mathrm{H}_{2}$ fuel cell systems [4]. But also marine [5] or aviation [6] applications require large range operation and therefore the highest 


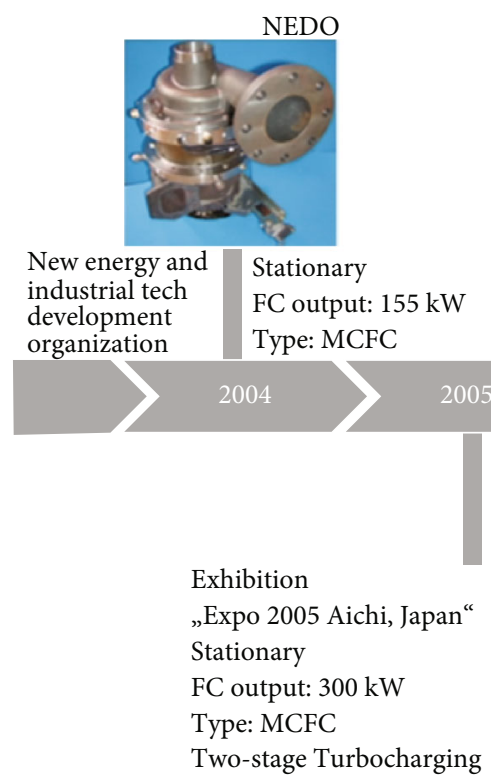

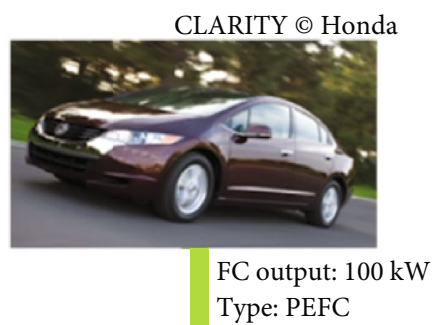

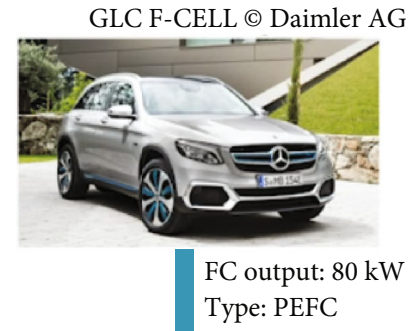

Type: PEFC

FIgURE 1: Timeline on IHI history on fuel cell applications.

on-board power storage with the lowest weight and volume. Therefore, hydrogen fuel cells are attractive solutions for future carbon-free mobility.

Moreover, for such applications, Total Cost of Ownership (TCO) is to a large extent dominated by operational cost and not so much ruled by installation cost, as is the case for individual use passenger car vehicles. This is important to achieve market acceptance also with a product price level suffering, yet from limited market penetration. Better market penetration which will lead to higher production numbers will allow to have attractive fuel cell system product pricing. As a self-strengthening process, this in turn will develop further markets for fuel cell systems. Operational cost from $\mathrm{H}_{2}$ fuel cost is also still on a level that needs improvement, but current public and government attention and activity organized via national $[7,8]$ and international initiatives (e.g., EU alliances) [4-6] allow to expect investment in related infrastructure and attractive fuel pricing.

Hydrogen fuel cell technology is identified as one option for allowing efficient vehicular propulsion with the least environmental impact on the path to a carbon-free society [9]. Fuel cell vehicles (FCV) can contribute to reducing greenhouse gas emissions. Hydrogen is a clean and flexible energy carrier. When generated by renewable "green" energy sources, greenhouse gas emissions can be reduced to zero. Refuelling takes only a few minutes, employing known technology. Realized travel distances of FCV for passengers are already well above $500 \mathrm{~km}$; efficient long haul operation is feasible. Local emission is water only; therefore, fuel cell vehicles are zero emission vehicles. The tank-to-wheel fuel cell system efficiency is in the range of $60 \%$ and therefore higher than for an internal combustion engine (ICE) [3]. Fuel cells operate quietly as there is no noise from intermittent combustion processes. There are no mechanical gears needed, as propulsion is realized by an electric motor. Fuel cells have a broad range of applications. In the transporta- tion sector, these are heavy duty and transit, light and medium duty, auxiliary power for refrigeration trailers and trucks, forklifts, and maritime use. Applications for stationary power, such as backup power for cell tower sites, combined heat and power, and data centres are considered, and also, base load power generation as well as portable power supply is possible.

Since more than 20 years, IHI is providing charging systems for stationary fuel cell applications and since 2004 for mobile fuel cell applications. Depending on the fuel cell system requirements, which were of the molten carbonate (MCFC) or the polymer electrolyte fuel cell (PEFC) type, and the specific design, a variety of technical solutions was developed and realized resulting in a broad experience in pressurizing fuel cell systems (compare Figure 1). Screw compressor technology as well as two-stage turbocharging systems with pressure ratio well above 3.5 was provided and tested in stationary technology demonstrators as well as mobile applications in fuel cell vehicles [10-12]. The power range of the fuel cells was from $70 \mathrm{~kW}$ up to $300 \mathrm{~kW}$. Operation duration for the MCFC was more than 4500 hours, and a net thermal efficiency of $41 \%$ was achieved [12]. For providing the most suitable operational pressure for PEFCs, IHI, but also other researchers [13], identified centrifugal compressors as the most efficient devices. Turbine generators for achieving the best system efficiency were always amongst the technical solutions.

IHI uses its long-term experience in compression technology, thermal turbomachinery, and turbocharging to support the development of efficient fuel cell systems for mobile applications. Experience in automotive industry provides the fundament for efficient system engineering and lean development processes considering mass production. Figure 2 illustrates the integration of a turbine-assisted electric turbocharger (ETC) in the air supply system and the fuel cell stack system. 


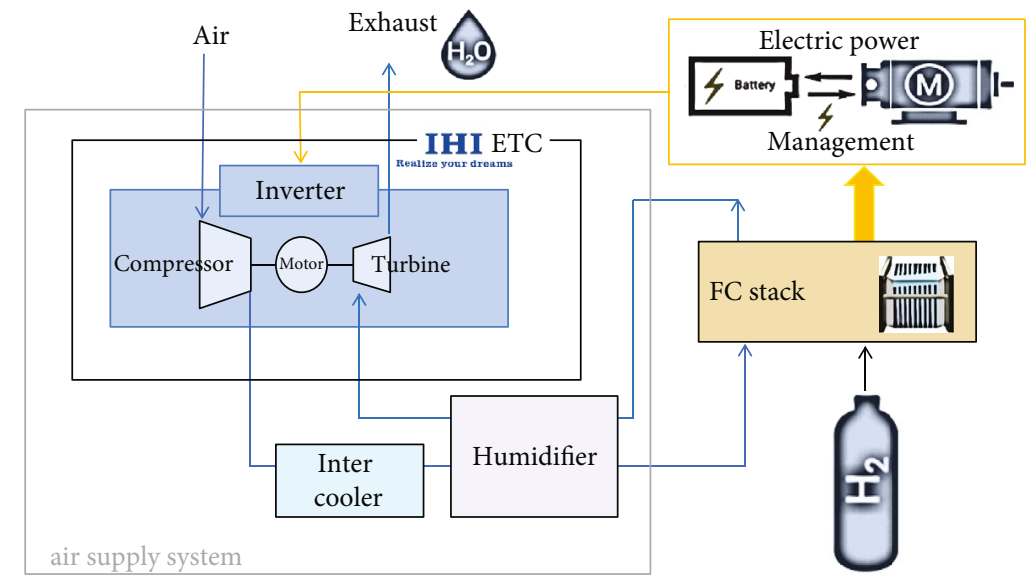

Figure 2: Simplified schematic of fuel cell system indicating the air supply system and the electric turbocharger (ETC).

\section{Pressurized Fuel Cells}

Power density and system efficiency are the most important for superior fuel cell systems. The power level is determined by the product of voltage and current. Both parameters are a function of the internal system pressure. Figure 3 from a principle investigation by Yan et al. [14] shows the effect of increased pressure on voltage and current for a proton exchange membrane (PEM) fuel cell, the most common for mobile applications. It is to note that, in the present paper, PEM and PEFC (polymer electrolyte fuel cell, compare above) are used as synonyms for the same type of fuel cells.

It is obvious that increased pressure increases voltage and current output, but pressures above three atmospheres are with limited effect on further power increase. Pressurized operation will also have a positive effect on the size of the humidifier and the heat exchanger helping with power volume relation of the stack system. Considering the effort for compression and also for bonding technology to achieve stack tightness, the operation pressure of fuel cell stack is best compromised in the range between 2.5 and 3.0 atmospheres [15-18]. Sufficient capability of the compression system for achieving related pressure ratios also considering operation under high altitude and/or high temperature conditions is required. In contrast to naturally aspirated systems, actively pressurized fuel cells allow compensation of low inlet pressure (altitude) and high inlet temperature (hot land) conditions via the compression system. Experience from turbocharging internal combustion engines with highly efficient thermal turbomachinery can be utilized. Modern gasoline Miller engines or state-of-the-art diesel engines are operated with similar pressure ratios [19]. Compare for example Scharf et al. [20]. Experience on sizing and optimizing the compression system in terms of map widths, pressure ratio, and maximum mass flow in the context of certain power derating under extreme high altitude or temperature operating conditions can also be transferred from state-of-the-art turbocharger development. Very high pressure ratios would lead to the need of more complex twostage systems. Very high flow rates will lead to rather large components with the related effect on rotor dynamics, thrust loads, transient response, and weight and size of the machine. Again, compromising is required to have, depending on the mission of the fuel cell application, the most efficient operation under regular (cycle relevant) long-term operation, but also covering short-term requirements as far as possible and meaningful. Thus, compromising in the layout of the thermal turbomachinery can be best weighted if relevant missions, described by transient and steady-state power demand, fuel cell stack power, and battery sizing, are considered. A schematic of the system including fuel cell, battery, and e-motor is also shown in Figure 2. The FC stack power needs to cover at least the steady-state (long haul) requirements. In combination with the battery capacity, the offered electric power needs to be sufficient to serve requirements also considering short-term demands for acceleration and other manoeuvres. The battery can also be charged utilizing energy from regenerative braking. The emotor is powerful enough to serve all vehicle manoeuvres.

It needs to be mentioned that also other technologies can be and have been applied to pressurize fuel cells. Superchargers with their immediate response were used for early mobile applications. Their pressure ratio is limited and efficiency of thermal turbomachinery is superior. Considering the rather silent e-drive system, the integration of superchargers into modern fuel cell propulsion systems will also be challenged by noise issues [10].

\section{Why Apply a Turbine for the Fuel Cell Air Compressor?}

For pressurizing the fuel cell stack, a substantial amount of energy is needed. The amount of energy is determined by the fluid mass flow, the intended pressure ratio, and the compression efficiency. Substantial energy is contained in the "exhaust gas" of the fuel cell stack, which can be utilized to assist the compression. In Figure 4(a), the compression power for a given mass flow for pressure ratio in a range between 1.5 and $>3.0$ is shown. In the same graph also, the available power at the turbine is given. The efficiencies of the turbine and the compressor were set constant to the value of 0.75 . Assumptions are taken for the stack outlet or turbine inlet temperature $\left(90^{\circ} \mathrm{C}\right)$ as well as the gas 


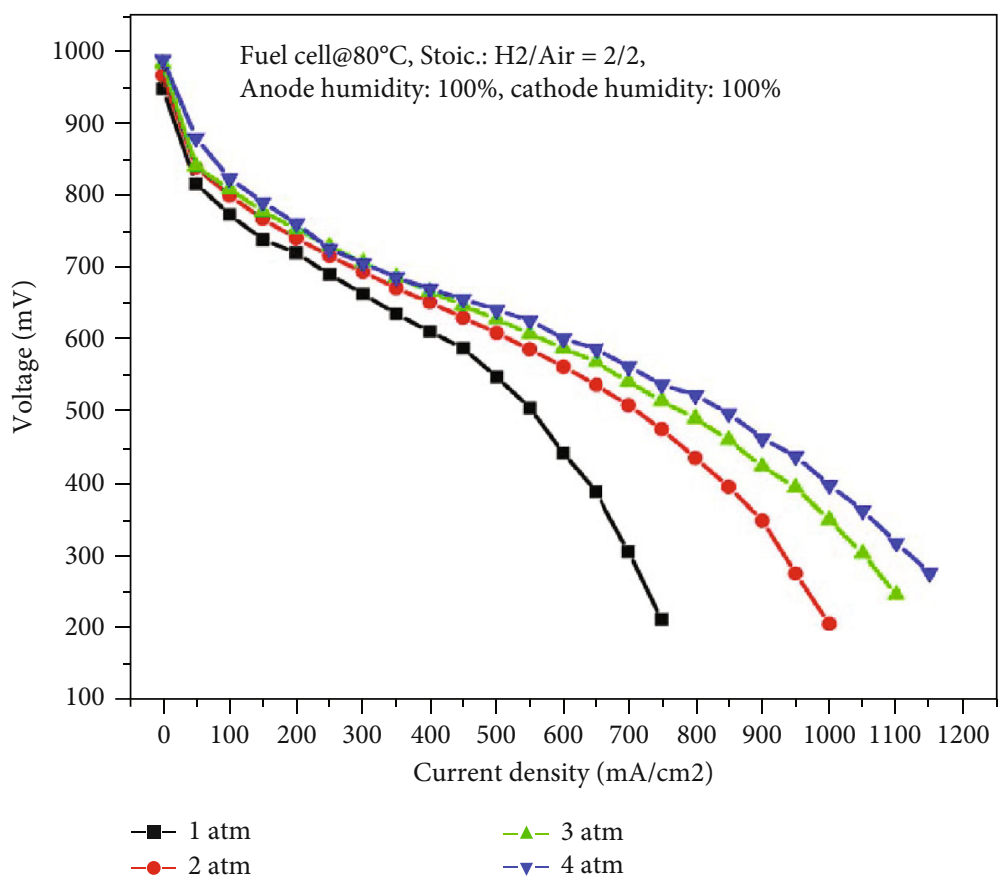

FIGURE 3: Principle effect of air pressure on fuel cell performance under certain assumptions; Yan et al. [14].

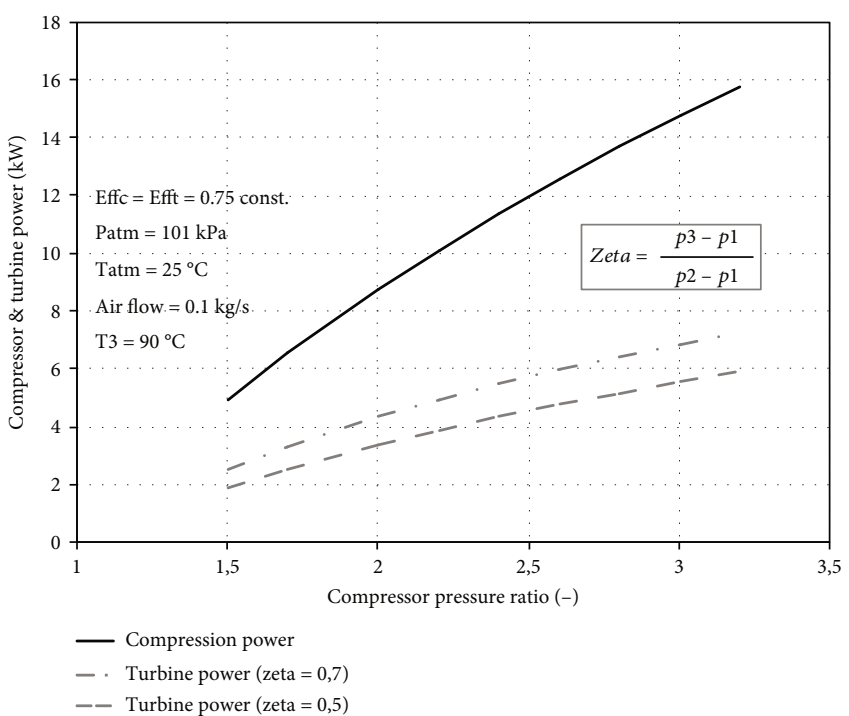

(a)

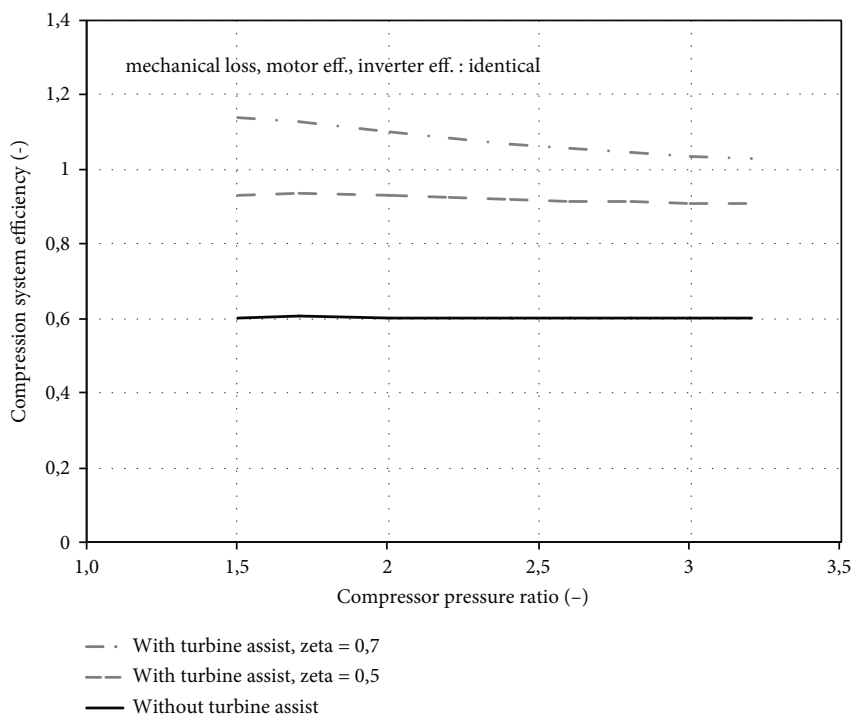

(b)

Figure 4: (a) Power for compression and possible turbine assist and (b) compression system efficiency under different conditions.

composition. The available turbine power also depends on the pressure loss within the stack or the available pressure drop across the turbine. Two cases are considered. The dashed line shows the turbine power under higher pressure drop conditions, whereas the turbine inlet pressure $p_{3}$ is calculated from the relation describing $\zeta$ :

$$
\zeta=\frac{\left(p_{3}-p_{1}\right)}{\left(p_{2}-p_{1}\right)}
$$

$p_{1}$ is representing the ambient pressure, $p_{2}$ represents the stack inlet pressure, and $p_{3}$ represents the turbine inlet pressure. The friction, motor, and inverter losses are a function of the rotational speed and therefore the pressure ratio. These losses are considered to be the same for all compression systems. Additional assumptions are no condensation in the turbine and air fuel ratio related to stoichiometric conditions, lambda, of 1.8 .

Obviously, a smaller pressure loss of the stack or higher available pressure drop at the turbine, represented by higher 
$\zeta$ values, supports turbine assist and leads to reduced demand on electrical power for the compression. A compressor system efficiency $\eta_{\text {sys }}$ can be quantified by dividing the theoretical compression power $(\dot{m} * \Delta h)_{\text {compressor }}$ by the inverter input power $P_{\text {inverter }}$ :

$$
\eta_{\text {sys }}=\frac{(\dot{m} * \Delta h)_{\text {compressor }}}{P_{\text {inverter }}} .
$$

The inverter input power needs to cover the actual power for compression $(\dot{m} * \Delta h / \eta)_{\text {compressor }}$ plus the losses from friction $P_{\text {friction. }}$. Efficiencies $\eta$ of the e-motor and the inverter increase this value, but it is reduced by the power that is recuperated by the turbine $(\dot{m} * \Delta h * \eta)_{\text {turbine: }}$ :

$$
P_{\text {inverter }}=\frac{(\dot{m} * \Delta h / \eta)_{\text {compressor }}+P_{\text {friction }}-(\dot{m} * \Delta h * \eta)_{\text {turbine }}}{\eta_{\text {e-motor }} * \eta_{\text {inverter }}} .
$$

Turbine recovery or turbine recuperation $R$ is expressed by relating the power that is generated by the turbine to the power that is needed for the air compression:

$$
R=\frac{(\dot{m} * \Delta h * \eta)_{\text {turbine }}}{(\dot{m} * \Delta h / \eta)_{\text {compressor }}} .
$$

Depending on actual losses in the electronic system and the compressor efficiency, this compressor system efficiency is by far smaller than unity without turbine assist as is shown in Figure 4(b). If the e-motor is assisted by a turbine, the compressor system efficiency increases, since approximately $25 \%$ to $30 \%$-in the best matching operation, even higher assist is possible - of the required compressor power can be provided by the turbine. Advantageous is that not only the system efficiency increases but also the available stack output power is increased, since the loss from compression is reduced by the power from turbine assist. Moreover, the emotor and inverter size can be reduced. Certainly, a proper integration of the turbine into the system with related piping needs to be ensured.

Several technology options can be considered, e.g., twostage compressors with intercooling between the compressor stages. However, the highest output power and the best efficiency systems are achieved by applying a turbine to assist the compression. This is even more valid as low-pressure drop stacks are utilized. The discussion if the turbine needs to be with variability is a lively one. Results from principal investigations to assess these technology options will be given later in this paper. In the following section, a brief description of the turbine-assisted electrical turbocharger for fuel cell application is given.

\section{Turbine-Assisted Electrical Turbocharger for Fuel Cell Applications}

Figure 5 shows the schematic of the components assembling the turbine-assisted electrical turbocharger for fuel cell applications. Basic technology development as described in [21] is supporting the product development. Compressor and turbine are arranged on one shaft. The rotor is supported by air bearings to prevent contamination of the fuel cell membrane by hydrocarbons. Any thrust force that is not balanced is compensated by the thrust bearing, which is of a foil type like the radial bearing. The electric motor is located between the two radial bearings. Cooling is realized by water flow to the electric motor, but also by cooling air taken downstream of the heat exchanger that is guided to the air bearings. The attached inverter is supplying the motor with electric power but is also providing the interfaces for electrical integration into and communication with the vehicle infrastructure. It is cooled with water from the lowtemperature cooling loop. It can be mentioned that the herewith described turbine-assisted electrical turbocharger was realized in hardware and was object to substantial validation and testing. The data utilized for the system comparison is based on these measurement campaigns. In particular, all performance data is based on experimental experience.

4.1. Centrifugal Compressor. Centrifugal compressor technology is utilized for pressurizing the fuel cell. A typical compressor map with its characteristics is shown in Figure 6. This is based on experimental results that are obtained with very similar equipment described in [22], but with fewer difficulties in considering heat flows. Such kind of technology excels with outstanding efficiency but has operational limits that need to be respected. For lower mass flows, the surge limit needs to be respected. This is a system limit that is also influenced by volumes of neighbouring components [23]. Operation with lower mass flows than indicated by the surge line is not possible. The maximum mass flow is limited by choke which is determined by the minimum flow area of the compressor stage along the flow path. The maximum rotation speed is limited by strength criteria and rotor dynamics, whereas the loading is dominated by centrifugal stress. The best efficiency and map width compromise can be achieved if the best efficiency pressure ratio is on a level below 3.0. In the electrical turbocharger, the layout of the compressor stage needs to be adapted to the speed that allows electric operation. Therefore, the electrically driven compressor comprises a specific design differing from standard ICE turbocharger compressor designs. High specific pressure ratios are realized to have the best combination with the electric drive. The number of blades is increased, and backward curvature at the blade outlet is rather low. Mass flow adaptation can be achieved by scaling or trimming of the compressor stage [23]. Scaling is meant as a geometrical change with a constant factor in all three spatial dimensions, whereas certain tolerance and minimum dimensional limits need to be respected. Trimming is understood in a way that the compressor wheel tip contour is modified while the basic compressor stage geometry is kept unchanged. Figure 6 shows a comparison of maps that are scaled, respectively, trimmed, to $85 \%$ of the original mass flow capacity and compared to a base map. Thereby, the factor for the map modification determines the change of maximum flow area and is therefore proportional to the change 


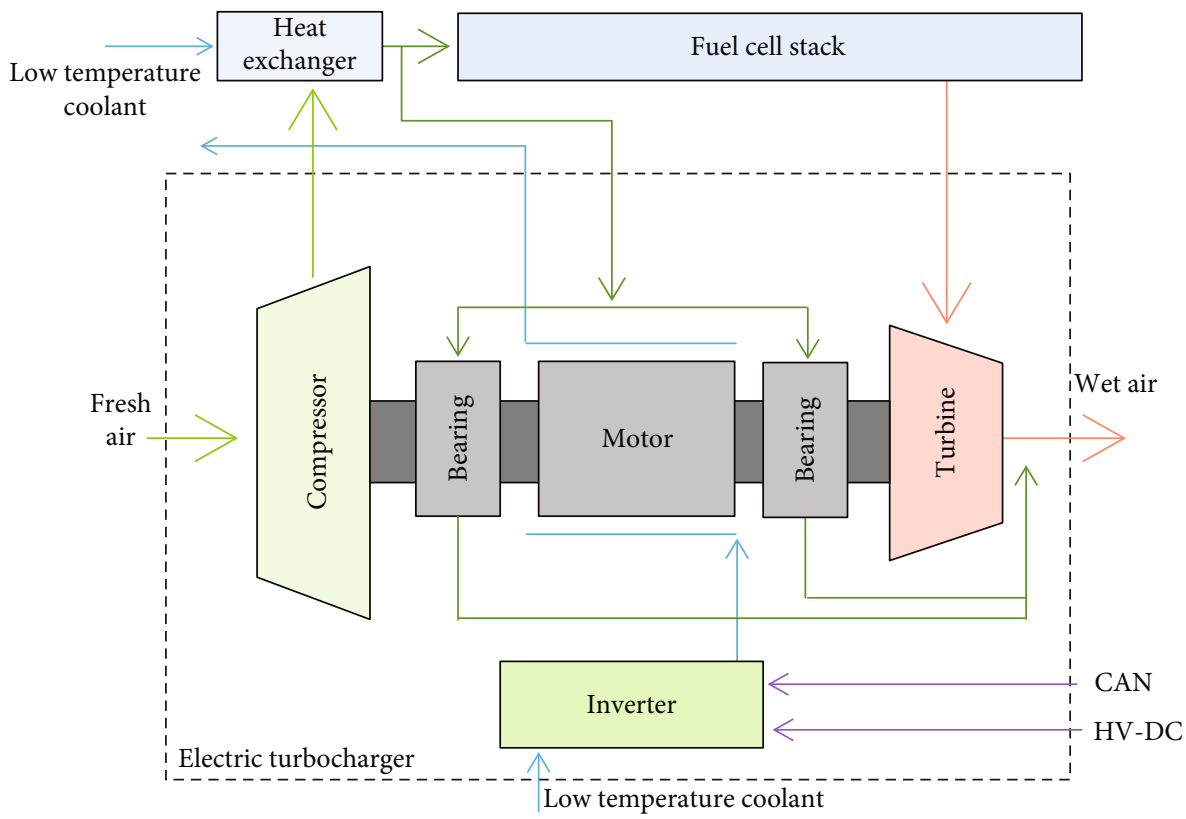

FIGURE 5: Schematic of components of electrical turbocharger.

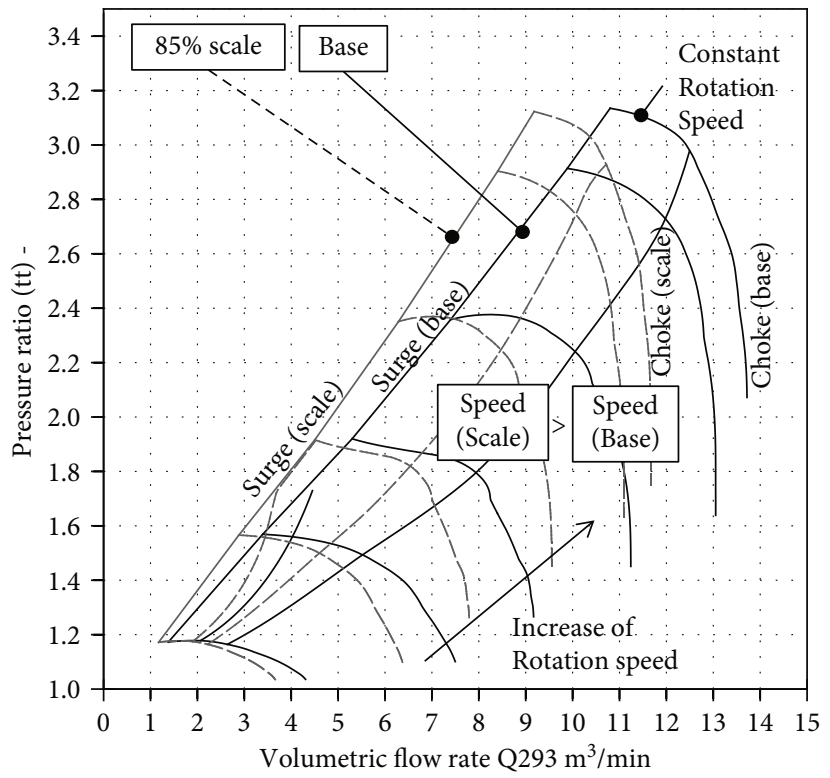

(a)

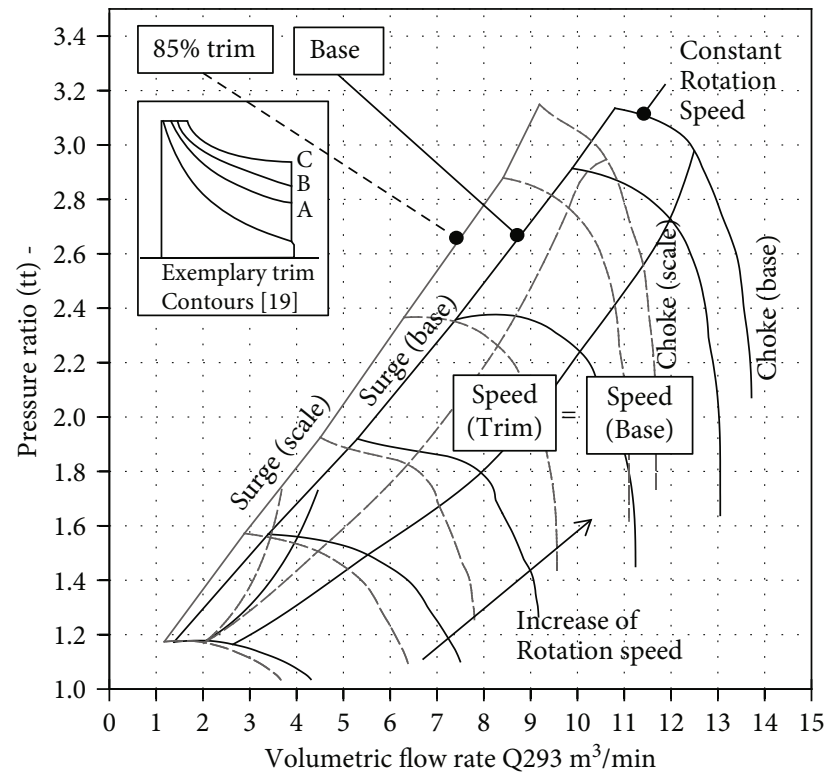

(b)

FIgURE 6: Comparison of compressor maps: (a) base map vs. scaled map; (b) base map vs. trimmed map.

in mass flow. At first sight, the scaled or trimmed maps look very similar. Dominant difference is the change of rotational speed for the scaled version. Scaling down requires higher rotational speed for achieving the target pressure ratio due to a reduced compressor outlet diameter. In the trimmed version, the target pressure ratio does not change the required rotational speed, which is advantageous in combination with an electric drive. Neglecting minor tip clearance effects, scaling in a limited range conserves the efficiency level of a compressor family. Having an optimized compressor as a base, trimming needs to be done with care since effi- ciency might decrease due to resulting small blade heights and therefore changed blade loading. Stronger trim might suffer from larger relative fillets and larger relative tip clearance due to reduced blade height. Trimming up needs also care to not sacrifice efficiency and stability at low flow rates due to increased curvature at the shroud and larger blade heights in the inducer area. Also, stress limits need to be carefully considered if the compressor is trimmed up.

Since stress loading needs to be kept below the material limits, larger components will allow only lower rotational speed. This has an effect on the layout of the motor; the 
inertia of the components will increase with a negative effect on transient response, whereas in an electrified turbocharger this can commonly be compensated by the e-motor. Also, the thrust capability of the bearings needs to sufficiently account for this. The principle relation is that larger component diameters will cause higher thrust forces. The compressor has stronger influence on thrust than the turbine due to the higher acting pressures and diameters, respectively, pressurized surface areas. Customizing map characteristics is possible by adjustment of specific speed and specific work coefficient through modifications of blade profile and blade height as well as diffuser and volute design [24]. Vaned diffusers offer the possibility of achieving higher pressure ratios with some adverse impact on map width $[19,23]$. State-ofthe-art optimization methods [25] with multiobjective optimization targets are utilized to realize the best efficiency base compressor designs. Scaling and trimming allow adaptation to the application-specific requirements of a fuel cell system.

In a later chapter, the paper at hand addresses the possibility of two-stage compression systems and gives an assessment in comparison to the one-stage system.

4.2. Electric Motor and Power Electronics. The electric motor is of a surface permanent magnet type. The design of the mechanical reinforcement of the rotating permanent magnet is challenging, and the choice of suitable material for the armour ring is decisive. It is considering the strength limits of turbine, compressor, and rotor shaft. The allowable maximum rotational speed of the turbocharger is respecting these. The rare earth magnet is with high magnetic energy density. The synchronous electric motor has two poles. The windings are realized to maximize the amount of copper in the available design space. It comprises the best speed stability and low variation resulting in favourable low noise behaviour.

Features of power electronics and electric motor interaction are vector modulation and sensor less control. The switching frequency is on a sufficiently high level to allow control for rotational speeds well above $100 \mathrm{krpm}$. The coil temperature is monitored for ensuring efficient and safe long-term operation. The inverter is attached to the motor housing for avoiding EMC issues which is increasingly difficult to contain with increasing distance between motor and inverter. Reliable operation also needs to consider environmental influences. Avoiding humidity and sealing against water are indispensable. Therefore, sealing of the connector interface between motor and inverter was introduced. In this regard, also the plug and related connector were enhanced. Special care was taken on waterproof interfaces integrated in the plug connector, which is installed at the motor side. The electronic inverter is integrated into the turbocharger.

The power of the electric motor is defined via the power request for compression. Considering the recuperation power from the turbine allows a layout of a reduced electric motor capability compared to compression systems without turbine assist. This improves the compactness of the design, but also reduces the inertia of the rotor. The acceleration behaviour of the machine is improved. This also is one important mode of operation that requires low rotor inertia and high efficiency of the turbomachinery. This mode defines the peak motor torque requested for starting up the fuel cell system in a sufficient short period of time, assuming always that the electric turbocharger can be served with sufficient electric energy.

4.3. Oil-Free Air Bearings. Contaminants from air supply components, like structural materials, lubricants, adhesives, sealants, and hoses, have been shown to affect the performance and durability of fuel cells-in particular the highly sensitive membranes. Therefore, the charging system which increases the pressure and therefore the power density of the stacks needs to be oil-free. Bump foil air bearings have been selected to support the rotor of the investigated fuel cell turbocharger in radial and axial direction. The air bearings allow stop-start operation and therefore a complete shutdown of the system in the absence of any energy demand. The coated and shaped foils provide sufficient robustness for multiple events under mixed friction conditions. The gas bearings need to offer excellent damping behaviour under high-speed operation, which is mandatory especially in vehicular applications [26]. :For predicting bearing loads and the displacement characteristic of the rotor, a dedicated simulation procedure was developed.

Utilizing this procedure, limits of the rotor displacements under vibrations could be defined. For safe and durable long-term operation, the bearings are cooled. The minimized pressure losses in the cooling passages were adjusted for the best distribution of the cooling air in the centre section and the electric motor.

4.4. Radial Turbine. Radial flow turbine technology is utilized for reducing the need of electric motor power to drive the compressor to pressurize the fuel cell. A typical fixed geometry turbine (FGT) map with its characteristics is shown in Figure 7. This is based on experimental results that are obtained with very similar equipment described in [22], but due to the low temperature level compared to conventional ICE turbochargers with electric heating of the turbine inlet mass flow. The lines give the relationship between mass flow and pressure ratio. The scaled map is showing a reduced mass flow of $85 \%$ compared to a base map. Thereby, the factor for the map modification determines the change of maximum flow area and is therefore proportional to the change in mass flow. The speed of the scaled turbine wheel is higher due to the lower turbine inlet diameter.

Available assist power is closely linked to the pressure loss over the fuel cell stack and to the composition of the gas at the inlet. The best efficiency operation for pressure ratio between 2.0 and 3.5 can be expected, but depends on the specific layout of the turbine stage. Under typical pressure and temperature conditions in fuel cells, fixed geometry turbines can generate up to $40 \%$ of the required power for compression, which is shown in detail below. Mass flow adaptation can be achieved by scaling of the turbine stage as shown above, respecting rotor dynamics and bearing load capacity. Customizing of the turbine map characteristics is possible by adjustment of specific speed and specific work coefficient by stator (volute and ring channel) design as well as modifications of blade profile and blade height as well as 


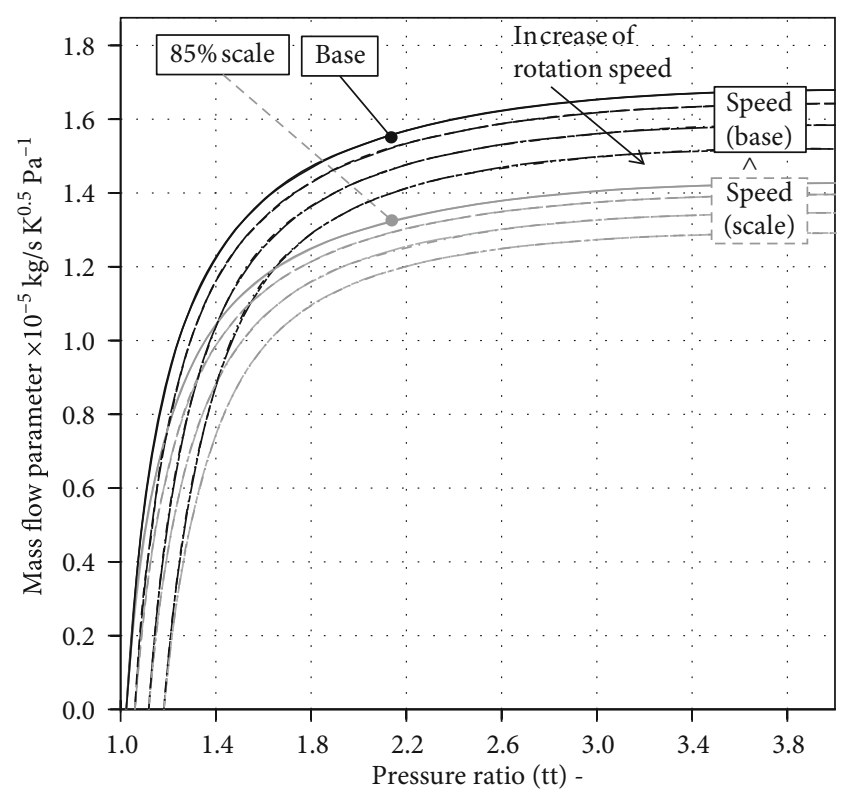

FIGURE 7: Comparison of turbine map: scaled vs. base map.

diffuser geometry. Decisive here is the suitable choice of degree of reaction for the design point and efficiency characteristics under varying operating conditions. Since fuel cells are operated under varying but steady-state conditions, turbine definition for fuel cells is simpler than for turbochargers for internal combustion engines. Still, all experience from turbocharger turbine design as well as from operation of centrifugal machines under condensation conditions can be overtaken [27-31].

Condensation and interaction with eventual droplets in the exhaust need to be accounted for in designing turbines for fuel cell applications. Based on experience with droplets from condensation in compressors [29] and from turbine applications in fuel cells, droplets at the intake of the turbine should be avoided by installation of a droplet separator. Nevertheless, substantial experimental effort was taken to quantify the turbine resistance against droplets, since droplets cannot necessarily be avoided for all operating conditions. Condensation from the change of state of the humid air during expansion in the turbine can be recognized, but does not harm turbine durability. Efficiency effects from condensation are known and can be considered [30, 31]. In any case, single-stage turbines are less affected than multistage turbines. Condensation effects are not considered in the given turbine maps.

In a later chapter, the paper at hand addresses the possibility of a variable turbine system (VGS) and gives an assessment compared to a fixed geometry turbine.

\section{Two-Stage Compressor with Intercooler vs. Turbine-Assisted Electric Turbocharger}

Figure 8 shows the investigated arrangements. A single-stage compression system with a turbine for recuperation is compared with a two-stage compression system with intercooler. For comparing the two concepts, the compression system efficiency is the most relevant. As described earlier, the compression system efficiency is calculated from the compression power related to the needed inverter power. It also has to be noted that the inlet temperature of the humidifier needs to stay below $100^{\circ} \mathrm{C}$. Therefore, an aftercooler needs to be considered for both compression systems. The intercooling in the two-stage system will have an effect on the total cooling power, but also the cooling power of the aftercooler. Therefore, this is a parameter that is also considered. Based on the cooling power, a rough estimation of sizes of the heat exchangers is elaborated.

The investigations assume a typical pressure loss of the intake air filter. For the estimation of the size of the heat exchangers, the surface area for heat transfer is used as an indicator. The temperature of the cooling medium is assumed to be $318 \mathrm{~K}$. Since the focus is on comparing the two systems, parameters like inverter and motor losses were assumed to be unchanged for both systems and for simplicity set to unity. This results in rather high efficiencies, but comparison under the mentioned assumptions is possible without any restrictions.

Figure 9 shows results of the zero-dimensional study. For the two-stage system, a split of 1.10 in single pressure ratios of the two stages was investigated. This split is based on experience with two-stage turbocharging systems and respects that the system in this study is assembled on one shaft. Both compressors need to comply with the same rotational speed. The low-pressure compressor is larger in diameter compared to the high-pressure compressor and therefore exhibits a higher tip speed which is relevant for the aerodynamic layout. This means that for the best efficiency layouts, the pressure ratio for the low-pressure stage should be higher than that for the high-pressure stage which comprises the lower tip speed. The map width and especially the surge limit restrict the selection of the split of the pressure ratios to values lower than 1.15. More detailed general information on two-stage charging systems can be found in [19].

The pressure ratio of the single-stage vs. the total pressure ratio is shown on the graph in Figure 9(a). Figure 9(c) shows the temperature after compression. The effect of intercooling, in this investigation down to $318 \mathrm{~K}$, is clearly visible, but the results prove that aftercooling is required for both systems. In Figure 9(c), the required temperature range at the humidifier inlet is indicated. The broken line describing the single-stage system indicates that operation for very high pressure ratio needs to be limited. For a pressure ratio of 3.5, the difference in outlet temperature is approximately $60 \mathrm{~K}$. In Figure 9(b), the compression power is compared. The broken, dotted line shows the power request for the single-stage compression system. The request for compression power for the two-stage system is reduced by the effect from intercooling, whereas this effect is only visible for total pressure ratios above 2.2 with related higher compression temperatures (A). Much stronger reduction of compression power is achieved by assisting the compressor with the turbine (B). In consequence, the compressor system efficiency of the turbine-assisted single-stage system is notably higher. This is shown in Figure 9(d).

The required cooling power is given in Figure 10. As expected, the total cooling power for the two-stage system 


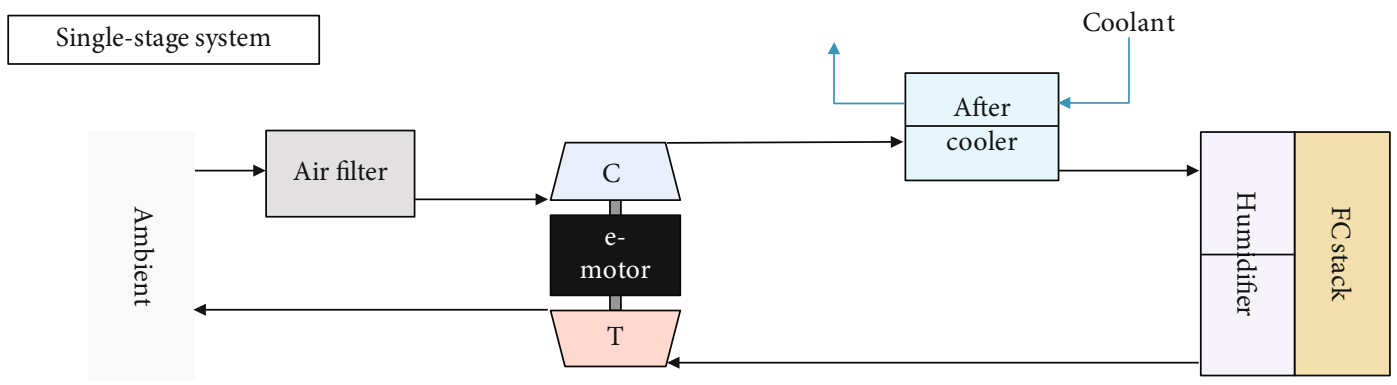

(a)

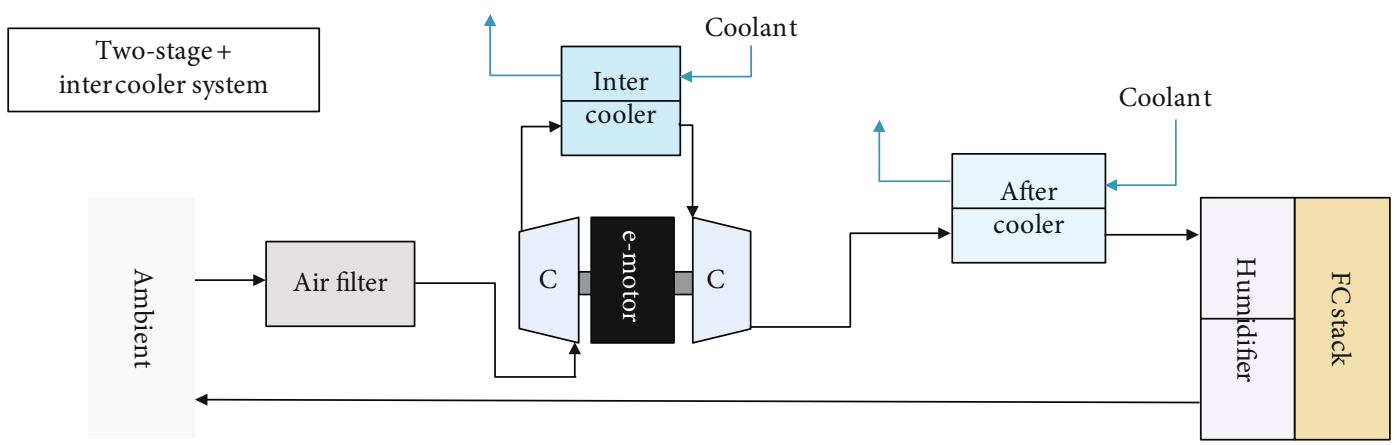

(b)

FIGURE 8: Schematic on compressor system arrangements: (a) turbine-assisted single-stage compressor; (b) two-stage compressor with intercooler.

is reduced. The amount of heat that is transferred in the intercooler is also shown in Figure 10. Assuming that similar types of heat exchangers comprise a nearly constant heat transfer rate $h$, the area for heat $\operatorname{transfer} A$ is defined by the heat flow $\dot{Q}$ and the given temperature difference $\Delta T$ across the heat exchanger.

$$
h=\frac{\dot{Q}}{A * \Delta T}=\text { const. }
$$

With this simple approach, the relative size and weight of the heat exchangers can be estimated, since in Figure $9(\mathrm{c})$ the temperatures are given and Figure 10 displays the cooling power or heat flows. For a pressure ratio of 2.8 and the split of pressure ratios of 1.10, the size of the two-stage aftercooler is then about $69 \%$ of the size of the single-stage system, whereas the single-stage system aftercooler size was defined as $100 \%$. But the two-stage system needs additionally an intercooler with a size that is about $86 \%$ the size of the aftercooler of the single-stage system. In total, this offers a package advantage for the singlestage system. This advantage is less pronounced with higher pressure ratios and therefore higher total cooling demand, but in any case, the two-stage system requires two cooling devices with the related implications for installation.

An extreme configuration might allow to eliminate the aftercooler while still keeping the temperature limit of the humidifier after compression by selecting an appropriate split of compression ratios. The target is here that the air temperature after the second compression is lower than the humidifier inlet temperature. Such configuration needs to have most compression in the first compressor stage, and therefore, the intercooler size will have to have nearly twice the size of the single-stage compression aftercooler with the related packaging disadvantages. Moreover, this extreme split of compression ratio will not allow the best aerodynamic performance as described above.

There is also the choice of turbine type. Based on decades of turbomachinery development, IHI has vast experience with turbines and their various inlet housing or inlet stator configurations $[28,32]$. Inlet variability is an option to adapt the turbine mass flow capacity to instantaneous needs of the fuel cell system, if operated under variable conditions.

\section{Variable Turbine vs. Fixed Geometry Turbine}

Once the geometry of a compressor stage is defined, the rotating speed of a radial compressor is determined from the mass flow and the requested pressure ratio. Figure 11 shows a typical map of a centrifugal compressor with its limits on the maximum flow (choke) and minimum flow (surge). Lines of constant speed and efficiency islands are indicated. For further discussion, the investigated operating points (OP) are indicated by coloured full circles. The grey circles in the compressor map in Figure 11(a) give the compressor operation. The blue coloured circles display the turbine operation in Figure 11(b). It is certainly most desirable to operate the compressor in the range of its best efficiency. For having the best system efficiency, the aerodynamicist will choose the geometric parameters of the turbine 


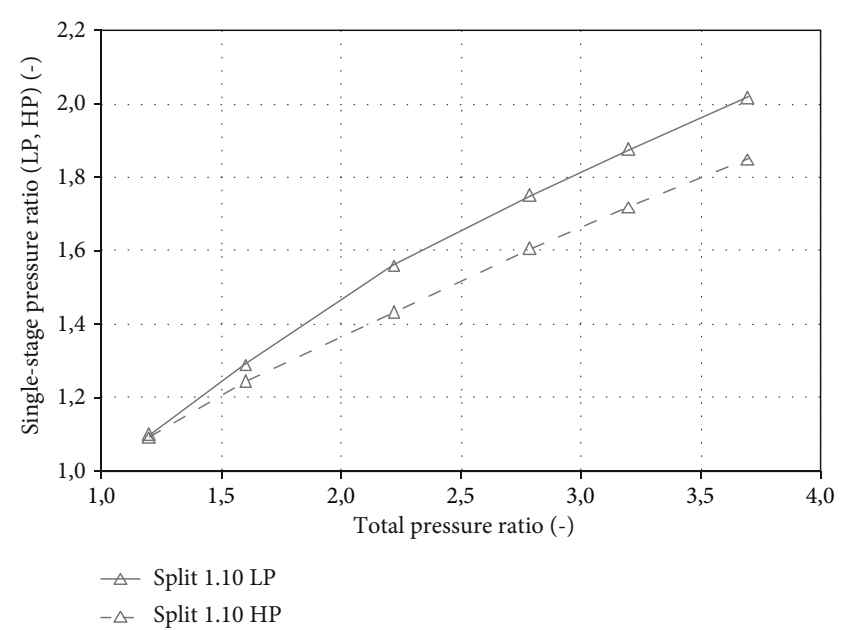

(a)

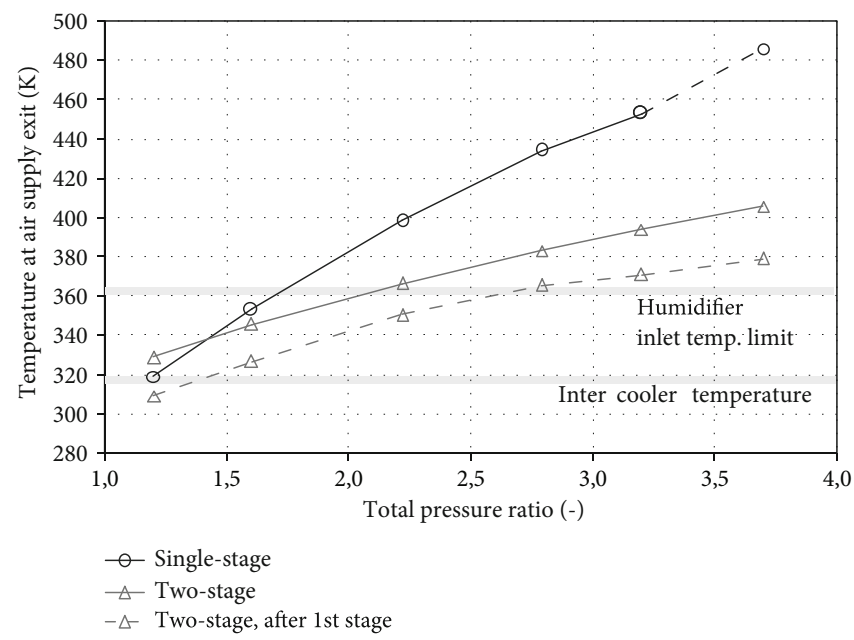

(c)

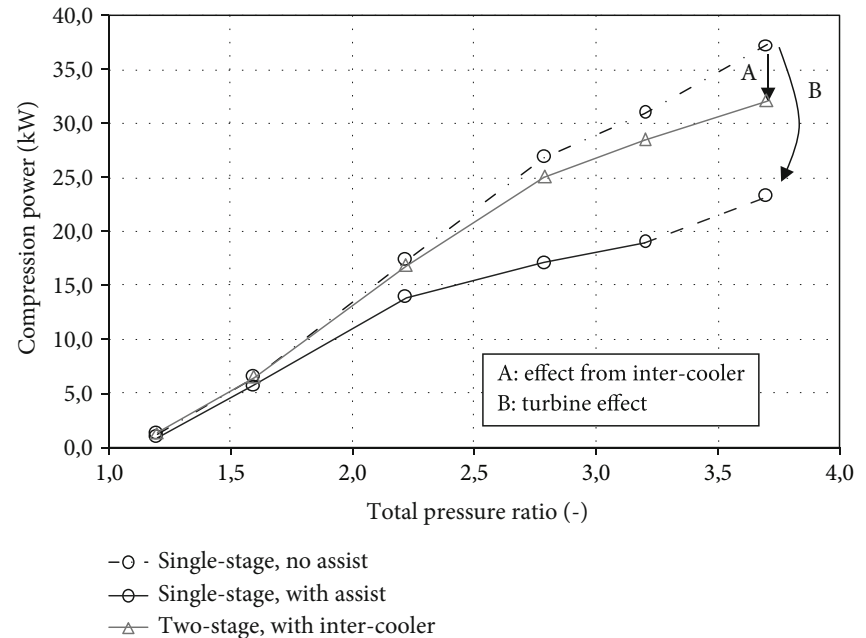

(b)

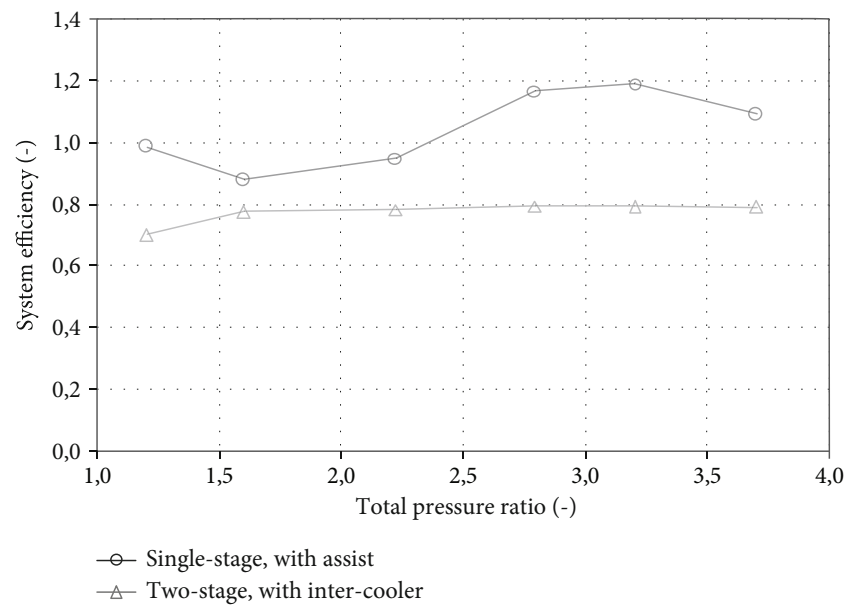

(d)

Figure 9: Comparison of single-stage with turbine assist and two-stage with intercooling: (a) single-stage pressure ratio vs. total pressure ratio; (b) power for compression with and without assist; (c) temperature after compression; (d) system efficiency.

stage in a way to ensure optimum efficiency along the requested characteristic of the machine.

In this example, operation in $\mathrm{OP}$ " $\mathrm{B}$ " requests best system efficiency. Therefore, the fixed geometry turbine is designed to "match" with the compressor operation in "B." This matching can be described by conditions that have to be met. Since the turbine and the compressor are mounted on one shaft, it is obvious that the rotational speed $n$ of compressor and turbine is the same:

$$
n_{\text {compressor }}=n_{\text {turbine }}=n \text {. }
$$

Moreover, the pressure ratio and mass flow characteristics of these two components need to match considering the properties of the fuel cell stack and installations:

$$
\dot{m}_{\text {compressor }}=f\left(\frac{p_{2}}{p_{1}} ; T_{1} ; n\right) \text {, }
$$

$$
\dot{m}_{\text {turbine }}=f\left(\dot{m}_{\text {compressor }} ; \frac{p_{3}}{p_{1}} ; T_{3} ; n ; \lambda\right) \text {. }
$$

Equation (1) defining $\zeta$ gives the relation between stack inlet pressure $p_{2}$ and turbine inlet pressure $p_{3}$ considering related losses. $T_{1}$ describes the inlet temperature of the compressor, and $T_{3}$ is the temperature at turbine inlet, which is determined by the stack inlet temperature after cooling and the heat release in the stack. $\lambda$ is the air fuel ratio, namely, the ratio between hydrogen and oxygen, which also impacts the turbine mass flow. In this study, $T_{1}=298 \mathrm{~K}, T_{3}=343 \mathrm{~K}$, and $\zeta=0.7$ for $\mathrm{OP}$ " $\mathrm{H}$ " and a constant air fuel ratio $\lambda=1.8$ are applied as typical values. Based on the component characteristics shown in the maps in Figure 11 and the requirements given in Equations (1), (6) and (7), the matching operation for compressor and turbine can be determined as illustrated with the bold, broken line. Thus, the best efficiency operation along this line does not require any variability of the turbine, but can be realized with a fixed geometry turbine. $\mathrm{OP}$ " $\mathrm{H}$ " can offer pressure ratio and mass 


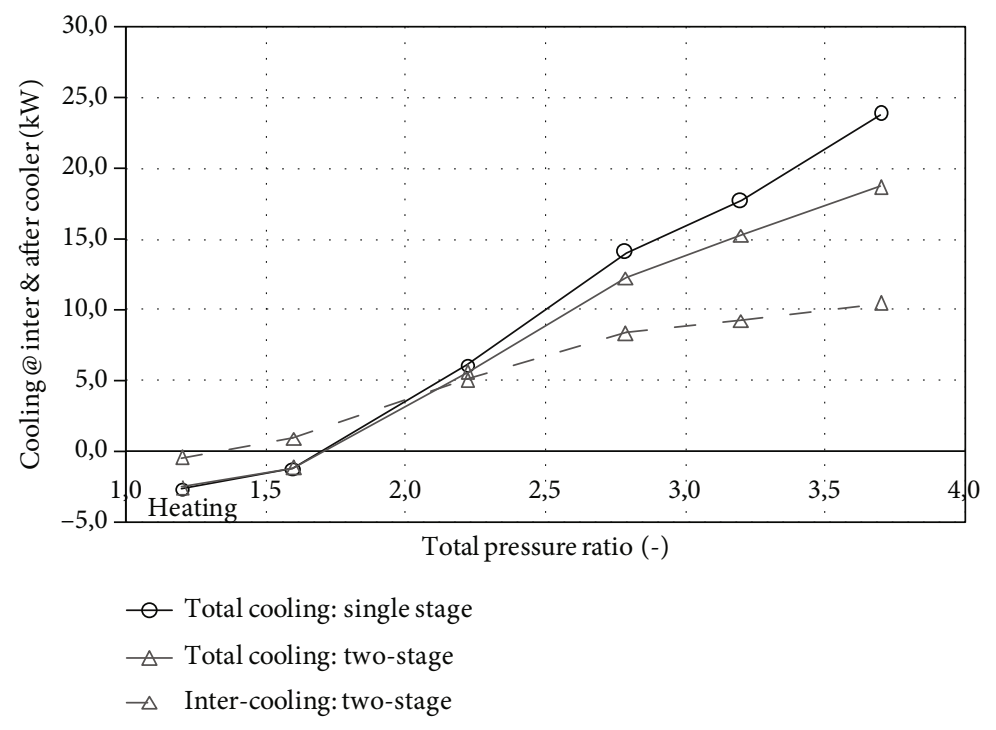

Figure 10: Total cooling power at inter- and aftercooler vs. total pressure ratio.

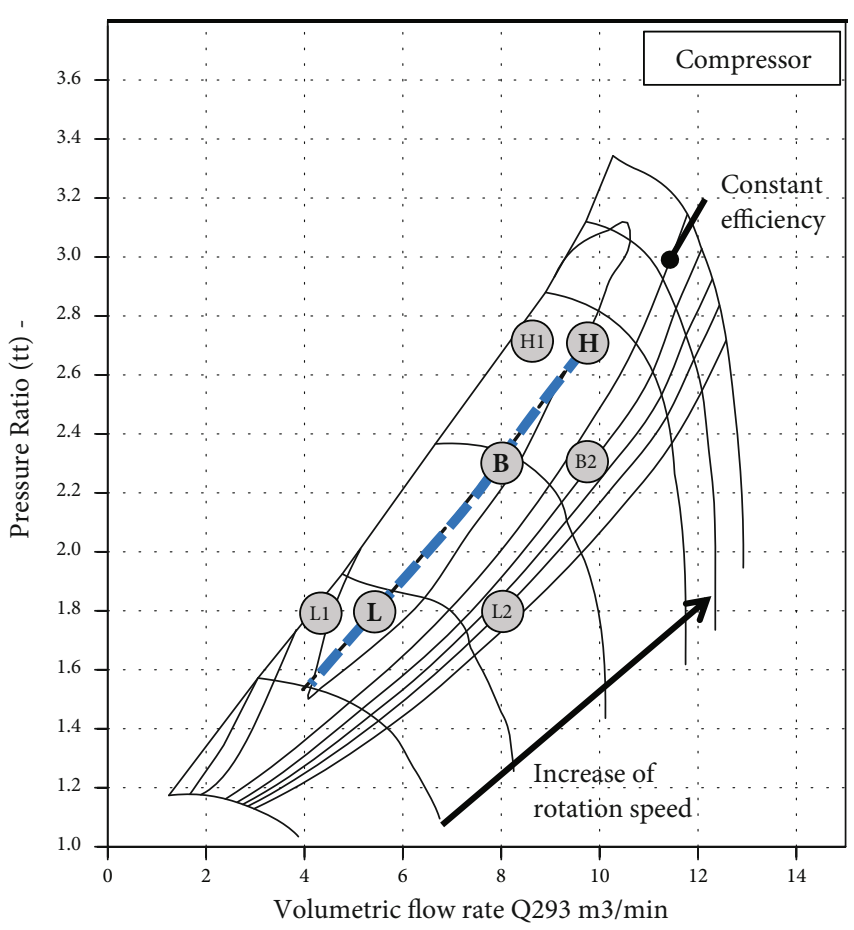

(a)

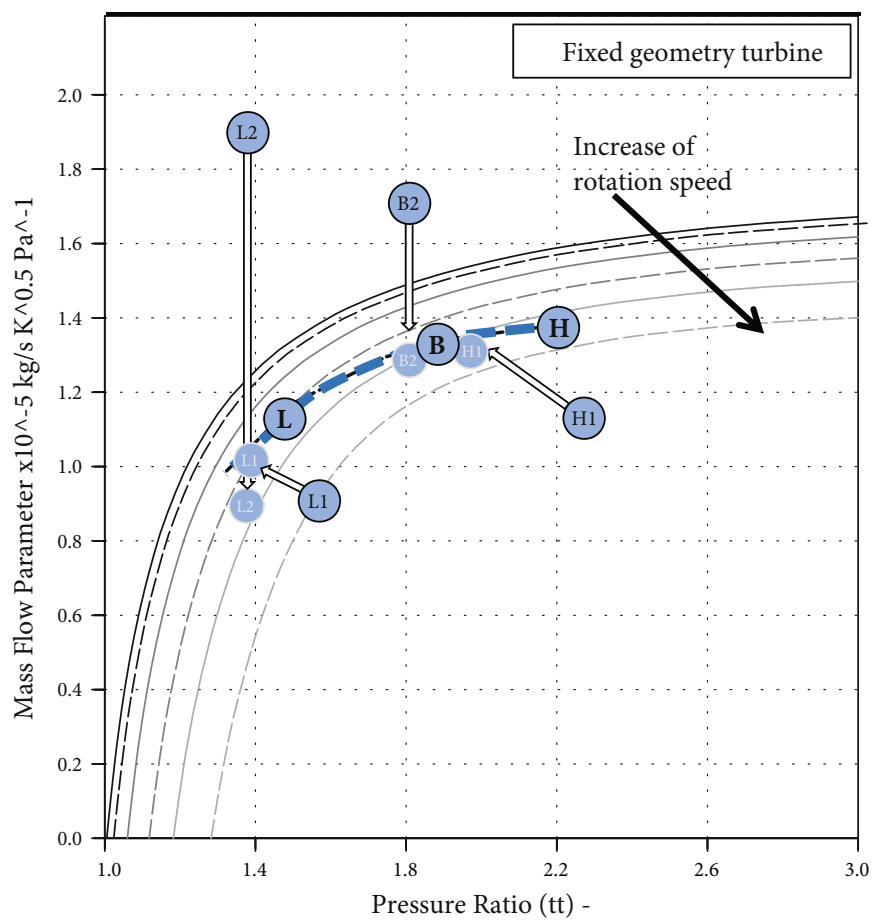

(b)

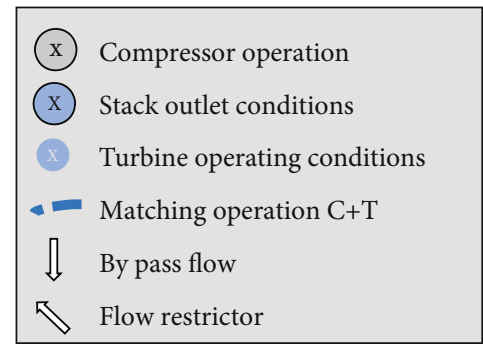

FIGURE 11: Compressor and turbine characteristics and investigated operating points (OP); (a) compressor; (b) fixed geometry turbine; OP L $+\mathrm{B}+\mathrm{H}$ : matching with FGT; OP H1+L1: operation close to surge; OP B2+L2: operation closer to choke. 
TABLE 1: Mass flow (MFP), pressure ratio (PR), efficiency (Efft), and turbine recuperation rate $(R)$ for different operating conditions (OP) of a fixed geometry turbine (FGT) and a variable turbine (VGS).

\begin{tabular}{|c|c|c|c|c|c|c|c|c|c|}
\hline & & OP & $\mathrm{H}$ & B & $\mathrm{L}$ & L1 & $\mathrm{H} 1$ & $\mathrm{~L} 2$ & B2 \\
\hline \multirow{2}{*}{ Stack } & $\mathrm{PR}$ & - & 2.21 & 1.90 & 1.51 & 1.57 & 2.28 & 1.37 & 1.81 \\
\hline & MFP & $\times 10^{-5}(\mathrm{~kg} / \mathrm{s}) \mathrm{K}^{0.5} \mathrm{~Pa}^{-1}$ & 1.38 & 1.34 & 1.17 & 0.90 & 1.15 & 1.93 & 1.72 \\
\hline \multirow{4}{*}{ Fixed geometry turbine } & PR & - & 2.21 & 1.90 & 1.51 & 1.38 & 1.97 & 1.37 & 1.81 \\
\hline & MFP & $\times 10^{-5}(\mathrm{~kg} / \mathrm{s}) \mathrm{K}^{0.5} \mathrm{~Pa}^{-1}$ & 1.38 & 1.34 & 1.17 & 1.02 & 1.33 & 0.91 & 1.27 \\
\hline & Efft & - & 0.75 & 0.75 & 0.74 & 0.68 & 0.71 & 0.52 & 0.70 \\
\hline & $R$ & $\%$ & $37.0 \%$ & $38.6 \%$ & $39.3 \%$ & $28.0 \%$ & $30.7 \%$ & $9.0 \%$ & $23.4 \%$ \\
\hline \multirow{4}{*}{ VGS turbine } & PR & - & 2.21 & 1.90 & 1.51 & 1.57 & 2.28 & 1.37 & 1.81 \\
\hline & MFP & $\times 10^{-5}(\mathrm{~kg} / \mathrm{s}) \mathrm{K}^{0.5} \mathrm{~Pa}^{-1}$ & 1.38 & 1.34 & 1.18 & 0.90 & 1.15 & 1.93 & 1.72 \\
\hline & Efft & - & 0.73 & 0.73 & 0.72 & 0.69 & 0.72 & 0.46 & 0.66 \\
\hline & $R$ & $\%$ & $36.3 \%$ & $37.8 \%$ & $38.5 \%$ & $38.4 \%$ & $36.6 \%$ & $16.8 \%$ & $30.0 \%$ \\
\hline
\end{tabular}

flow margin allowing operation under high altitude conditions without the need for derating of the stack power. The given operation " $\mathrm{H}$ " in this case allows inlet conditions at approximately $1500 \mathrm{~m}$ altitude, and the compressor is still delivering the same pressure at the stack inlet as for operation "B" under normal sea level conditions. OP "L" represents operation under low load. As soon as the operation deviates from this best efficiency operation, the fixed geometry turbine will not be operated under its best conditions. OP "L2" and "B2" were selected to show the effect when a bypass is needed and a portion of the exhaust gas energy cannot be utilized. "L2" comprises the same pressure ratio as "L" and the same flow as "B." "B2" has the same pressure ratio as " $\mathrm{B}$ " and the same flow as " $\mathrm{H}$." OP " $\mathrm{L} 1$ " and " $\mathrm{H} 1$ " require reducing the turbine pressure ratio to match the pressure ratio-mass flow characteristics of the given turbine. "L1" comprises the same pressure ratio as "L." "H1" has the same pressure ratio as "H." This operation is illustrated in Figure 11. Figure 11(a) shows the characteristics of a fixed geometry turbine that is sized to allow the best operation under conditions "L," "B," and "H." It also shows how operation in "H1," "B2," "L1," and "L2" needs to shift to match with the turbine design.

Assuming typical fuel cell operation with related pressure loss over the stack and gas conditions, the power from turbine assist for a fixed geometry turbine (FGT) and a variable geometry system (VGS) was compared. For both turbine types, the same compressor operation providing the pressurized inlet flow for the fuel cell stack, namely, compressor pressure ratio, volume flow, and rotating speed, was assumed. Pressure losses from the air inlet filter were neglected since this is no differentiator for comparing turbine operation. Also, the pressure losses in the exhaust piping after the turbine were neglected, since there is minor influence on actual turbine operation. In Table 1, the parameters of the seven operating points (OP) defined by the potential turbine pressure ratio $(\mathrm{PR})$ offered downstream of the stack and the related mass flow parameters (MFP) are listed. The table summarizes the results from this study comparing the two turbine types. Turbine pressure ratio, mass flow parameter, and efficiency (Efft) as well as the recuperation rate $(R)$ according to Equation (4) are given for both technologies. For the FGT, the (shift in) turbine operation is illustrated in Figure 11(b).

It can be noted that for most of the OPs, the difference is small. For OP "H," "B," and "L" under the best recovery conditions, the generated assist power of the fixed geometry turbine is higher than that for the variable turbine, since some gap losses in the stator can be avoided in a design of a FGT and therefore efficiency is higher. In OP "L," the relative recuperation is the highest due to the reduced pressure loss in the stack for low flow. The FGT reaches almost $40 \%$.

For OP "L1" and "H1," a variable turbine shows an advantage in turbine output power due to the higher usable pressure ratio and caused by this also better stage efficiency. The level of recovery for OP " $\mathrm{L} 1$ " and " $\mathrm{H} 1$ " with reduced mass flow compared to optimal operation is between $28 \%$ and $38 \%$. Recuperation is higher for the variable turbine, but the absolute power level is low. For OP "L1," the needed compressor power is only $6.3 \mathrm{~kW}$, compared to $25.4 \mathrm{~kW}$ for OP " $\mathrm{H}$." Respectively, the recuperation power for OP " $\mathrm{L} 1$ " is only $2.4 \mathrm{~kW}$ with the variable turbine and $1.8 \mathrm{~kW}$ for the FGT, a difference of $0.6 \mathrm{~kW}$ in absolute values. For OP "B2" and "L2," the efficiency of the variable turbine is reduced, but it can utilize the complete mass flow provided from the fuel cell stack, leading to recuperation advantage for the variable turbine. The recovery rate for OP "B2" and "L2" with increased mass flow compared to optimal recuperation is in the maximum $30 \%$. For OP "B2," the needed compressor power is $22.1 \mathrm{~kW}$. The recuperation power for $\mathrm{OP}$ "B2" is $6.6 \mathrm{~kW}$ with the variable turbine and $5.2 \mathrm{~kW}$ for the FGT, a difference of again $0.6 \mathrm{~kW}$ in absolute values. For "L2," the difference in recuperation power between the VGS and the FGT is $1.0 \mathrm{~kW}$.

Based on this investigation and targeting for the least design complexity, a fixed geometry turbine is considered suitable and appropriate for assisting compressors for fuel cell systems. For operation in the area of OP "L2" and "B2," with higher mass flow than for the best efficiency operation, a simple bypass is an appropriate option. Midflow 


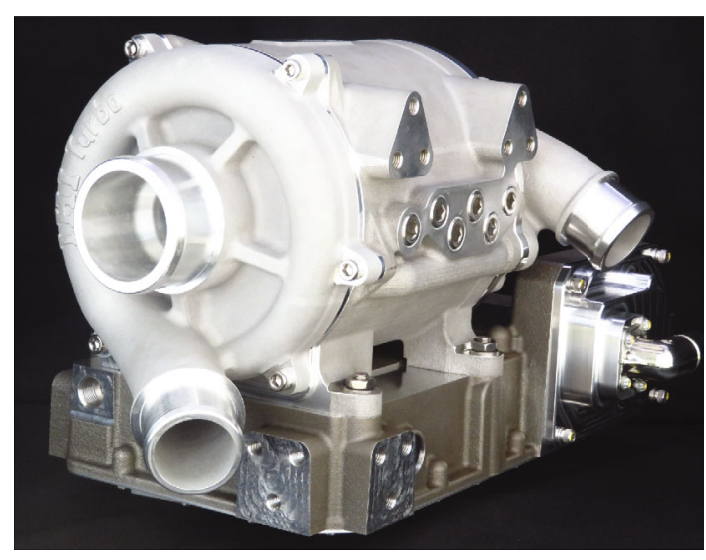

Figure 12: Photograph of the electric compression system with turbine assist and attached inverter.

range operation of the turbine-assisted turbocharger at the best efficiency is the most beneficial to reduce the electricity consumption. Such operation can be well served by a FGT.

\section{Summary}

The power density of fuel cells substantially increases if the system is pressurized. However, contaminants from fuel cell system components like structural materials, lubricants, adhesives, sealants, and hoses have been shown to affect the performance and durability of fuel cells. Therefore, the charging system that increases the pressure and hence the power density of the stacks inevitably needs to be oil-free.

For this reason, gas bearings are applied to support the rotor of a fuel cell turbocharger. It furthermore comprises a turbine, a compressor, and, on the same shaft, an electric motor. The turbine utilizes the exhaust energy of the stack to support the compressor and hence lowers the required electric power of the air supply system. The study at hand demonstrates that such a system is more efficient compared to a two-stage compressor system with intercooler. The turbine can produce more than $30 \%$ of the needed compressor power. Hence, it substantially increases the system efficiency. The turbine is designed to reliably operate with the best efficiency in a humid air environment: a certain amount of droplets and vapour can be tolerated. It was shown that a fixed geometry turbine design delivers optimal recuperation power. The compressor is of a low specific speed type with a vaneless diffuser. It is optimized for operating conditions in a fuel cell system regarding specified airflow and pressure ratio, which is typically in the range of 3.0. Accordingly, such electrified turbocharger enables higher power density fuel cell systems. The gas bearings allow start-stop operation and therefore a complete shutdown of the system, in the absence of any energy demand. The coated and shaped foils provide sufficient robustness for multiple events under mixed friction conditions. The gas bearings offer excellent damping behaviour under high-speed operation, which is mandatory in vehicular applications. Moreover, the electrified turbocharger system provides direct customer benefit since it is superior in noise behaviour compared to supercharger systems that served to pressurize earlier fuel cell sys- tems. The electronic inverter is integrated into the turbocharger as can be seen in Figure 12.

The oil-free turbocharger for fuel cell applications is providing the latest charging technology to serve emission-free propulsion systems. It is designed to allow scaling for application to different power level fuel cell systems. Multiple compression systems with turbine recovery are also an option for application to higher power-sized fuel cell systems. Hence, this technology is suited to support the achievement of indispensable sustainable development goals as requested by modern society.

This paper can serve as a base for allowing pressurized fuel cell system optimization utilizing existing experience with turbocharging systems. In future developments, the electric turbocharger needs to be treated as an integrated component of the fuel cell air supply. Optimizing the complete fuel cell system considering its thermal management, the properties of the centrifugal turbomachinery, but also the electronics will allow even better system power density, efficiency, and compactness.

\section{Data Availability}

The data used to support the findings of this study are included within the article.

\section{Conflicts of Interest}

The authors declare that there is no conflict of interest regarding the publication of this paper.

\section{Acknowledgments}

The authors are grateful to IHI Corporation for funding this work and for the permission to publish.

\section{References}

[1] U. Kramer, D. Göricke, and R. Thee, "Energy paths for road transport in the future," MTZ worldwide, vol. 80, no. 5, pp. 18-25, 2019.

[2] U. Kramer, F. Ortloff, and S. Stollenwerk, Defossilisierung des Transportsektors: Optionen und Voraussetzungen in Deutschland, Band 586 von Forschungsvereinigung Verbrennungskraftmaschinen R, Verlag FVV, 2018.

[3] G. Hutchings, M. Davidson, P. Atkins et al., Sustainable Synthetic Carbon Based Fuels for Transport: Policy Briefing, The Royal Society, 2019, ISBN: 978-1-78252-422-9.

[4] Y. Ruf, M. Baum, T. Zorn, A. Menzel, and J. Rehberger, Fuel Cells Hydrogen Trucks- Heavy-Duty's High Performance Green Solution, R. Berger, Ed., Fuel Cells and Hydrogen 2 Joint Undertaking (FCH 2 JU), 2020, ISBN: 978-92-9246-347-2.

[5] Y. Ruf, T. Zorn, P. A. De Neve et al., Use of Fuel Cells and Hydrogen in the Railway Environment, R. Berger, Ed., Fuel Cells and Hydrogen Joint Undertaking (FCH JU) and the Shift2Rail Joint Undertaking (S2R JU), 2019, ISBN 978-9295215-11-5.

[6] Hydrogen-Powered Aviation, A Fact-Based Study of Hydrogen Technology, Economics, and Climate Impact by 2050, 
McKinsey \& Company, Clean Sky 2 JU and Fuel Cells and Hydrogen 2 Joint Undertakings, 2020, ISBN 978-92-9246342-7.

[7] Bundesministerium für Wirtschaft und Energie (BMWi), Die Nationale Wasserstoffstrategie, Berlin, 2020.

[8] F. Gérard, L. van Nuffel, T. Smit et al., Opportunities for Hydrogen Energy Technologies considering the National Energy \& Climate Plans, Trinomics \& LBST, Fuel Cells and Hydrogen 2 Joint Undertaking, 2020, Reference number: FCH / OP / Contract 234.

[9] IHI Corporation, IHI integrated report, 2020, https://www.ihi .co.jp/csr/english/download01/pdf/integrated2020_E_all.pdf.

[10] C. Mohrdieck and S. Dehn, "The intelligent fuel cell plug-in hybrid drive system of the Mercedes-Benz GLC F-cell," MTZ worldwide, vol. 80, no. 1, pp. 30-37, 2019.

[11] M. Venturi, C. Mohrdieck, and J. Friedrich, "Mercedes-Benz B-Class Fuel Cell: the world largest hydrogen vehicle fuel cell fleet experience," in 2013 World Electric Vehicle Symposium and Exhibition (EVS27), Barcelona, Spain, 2013.

[12] K. Onda, T. Osaka, Y. Ogawa et al., Molten Carbonate Fuel Cell Power Generation Technology Development, Evaluation Report, Incorporated Administrative Agency New Energy and Industrial Technology Development Organization, 2005.

[13] B. Blunier and A. Miraoui, "Air management in PEM fuel cells: state-of-the-art and prospectives," in International Aegean Conference on Electrical Machines and Power Electronics, Bodrum, Turkey, 2007.

[14] Q. Yan, H. Toghiani, and H. Causey, "Steady state and dynamic performance of proton exchange membrane fuel cells (PEMFCs) under various operating conditions and load changes," Journal of Power Sources, vol. 161, no. 1, pp. 492502, 2006.

[15] B. Blunier and A. Miraoui, "Proton exchange membrane fuel cell air management in automotive applications," Journal of Fuel Cell Science and Technology, vol. 7, no. 4, 2010.

[16] A. C. Rojas, G. L. Lopez, J. F. Gomez-Aguilar, V. M. Alvarado, and C. L. S. Torres, "Control of the air supply subsystem in a PEMFC with balance of plant simulation," Sustainability, vol. 9, no. 1, p. 73, 2017.

[17] H. Liu, P. Li, A. Hartz, and K. Wang, "Effects of geometry/dimensions of gas flow channels and operating conditions on high-temperature PEM fuel cells," International journal of energy and environmental engineering, vol. 6, no. 1, pp. 75$89,2015$.

[18] M. Grujicic, K. M. Chittajallu, E. H. Law, and J. T. Pukrushpan, "Model-based control strategies in the dynamic interaction of air supply and fuel cell," Proceedings of the Institution of Mechanical Engineers, Part A: Journal of Power and Energy, vol. 218, 2004.

[19] N. Watson and M. S. Janota, Turbocharging the Internal Combustion Engine, The McMillan Press, 1982, ISBN 0-333-242904.

[20] J. Scharf, M. Thewes, A. Balazs et al., "All Clean Gasoline Hybrid Powertrains - Real Driving Emissions, Lambda $=1$ \& Euro 7," in Proceedings of the Aachen Colloquium Automobile and Engine Technology, Aachen, Germany, 2018.

[21] S. Yoshinaga, S. Aoyama, K. Yamaguchi, and T. Jikumaru, "Elemental technologies to realize electrification of high speed rotating machinery," IHI Engineering Review, vol. 54, no. 1, 2021.
[22] H. Mai and H. Bolz, "Validierung von Turboladerkennfeldern auf Heissgasprüfständen," in ATZ Extra - Prüfstände und Simulationen für Antriebe, pp. 54-58, 2015.

[23] M. Casey and C. Robinson, Radial Flow TurbocompressorsDesign, Analysis, and Application, Cambridge University Press, 2021, ISBN 978-1-108-41667-2.

[24] P. Harley, S. Spence, D. Filsinger, M. Dietrich, and J. Early, "Experimental and numerical benchmarking of an improved meanline modelling method for automotive turbocharger centrifugal compressors," in ASME TURBOEXPO 2015: Turbine Technical Conference and Expositition, Montreal, Canada, 2015.

[25] A. Starke, T. Bamba, D. Filsinger, and P. Harley, "An automatic optimisation of a centrifugal compressor for improved performance at near surge operation," in Proceedings of the International Gas Turbine Congress, pp. 495-501, Tokyo, 2015.

[26] A. Furuno and N. Omori, Design and performance evaluation of gas foil bearing for turbo blower, Japan Society of Mechanical Engineers, 2016.

[27] B. Lüddecke, D. Filsinger, and J. Ehrhard, “On mixed flow turbines for automotive turbocharger applications," International Journal of rotating machinery, vol. 2012, Article ID 589720, 14 pages, 2012.

[28] J. Walkingshaw, G. Iosifidis, T. Scheuermann, D. Filsinger, and N. Ikeya, "A comparison of a mono, twin and double scroll turbine for automotive applications," in Proceedings of ASME Turbo Expo, Montreal, Canada, 2015.

[29] D. Talmon-Gros, B. Huurdeman, B. Lüddecke, and D. Filsinger, "Analysis of components for low-pressure exhaust gas recirculation," MTZ-Motortechnische Zeitschrift, vol. 75, no. 3, pp. 44-49, 2014.

[30] S. Schuster, D. Brillert, and F.-K. Benra, "Condensation in radial turbines-part I: mathematical modeling," Journal of Turbomachinery, vol. 140, no. 10, p. 101001, 2018.

[31] S. Schuster, D. Brillert, and F.-K. Benra, "Condensation in radial turbines-part II: application of the mathematical model to a radial turbine series," Journal of Turbomachinery, vol. 140, no. 10, p. 101002, 2018.

[32] M. Rode, T. Suzuki, G. Iosifidis et al., "Boosting the future with IHI: a comparative evaluation of state-of-the-art TGDI turbo concepts," in 24th Supercharging Conference, Dresden, 2019. 